\title{
Evolution of the Concept and Models of Work Exhaustion (Burnout): The Research in Mexico
}

\author{
Juan Carlos Moreno Jiménez ${ }^{1}$, Mara Maricela Trujillo Flores ${ }^{1}$, Luis Arturo Rivas $\operatorname{Tovar}^{1}$ \& \\ Fernando Lámbarry Vilchis ${ }^{1}$ \\ ${ }^{1}$ Instituto Politécnico Nacional, Escuela Superior de Comercio y Administración, Unidad Santo Tomás, México \\ Correspondence: Juan Carlos Moreno Jiménez, Calle 16A, No. 11, Colonia Santa Rosa, México. E-mail: \\ carlosm-10@hotmail.com
}

Received: June 23, 2014

Accepted: July 16, 2014

Online Published: August 25, 2014

doi:10.5539/ibr.v7n9p45

URL: http://dx.doi.org/10.5539/ibr.v7n9p45

\begin{abstract}
This is a review paper which describes "Burnout", its concept evolution, Burnout models, which is divided into two types: comprehensive models and process models, identification of varying quantification instruments and application area, it is also analysed, described, and discussed the models and instruments weaknesses. Finally is described the research made in Mexico.

The main finding of the paper is that burnout is contingent with the environment and a phenomenon is important and the empirical evidence is too strong for to consider as occupational disease in the design of public policies to face the problem.
\end{abstract}

Keywords: Burnout, models, instruments, institutions of higher education, labor harassment

\section{Introduction}

In developed countries, the increasing incidences of unemployment levels are unprecedented in the modern age. According to Eurostat "unemployment in both the European Union (EU) and the euro area was placed at a record of 10.7\%" (cited in Notimex, 2013). In countries like Mexico, labor precariousness is manifested in massive rates of underemployment and informal employment. "For every formal employment that was generated in the past five years, three have been created in the informal sector. It is estimated that 77 of every 100 Mexicans were left without access to formal labor source" (Martínez, 2012).

This double pressure of threatens of unemployment, on the one hand, and precarious jobs with low wages and without social protection, has led to tremendous pressure on employees and workers who are fortunate to have a formal job.

Speaking of countries with different and particular labor realities, it makes sense to analyze the complexity and diversity in the organizations that subsist in these countries as well as their culture, norms, institutions, values, among many other things as a demonstration of multiculturalism and work conditions; according to the (Organisation for Economic Co-operation and Development [OECD], 2013) there are wide differences between countries in time devoted to work (paid and unpaid). In the study report "Society at a Glance 2013", among OECD countries, Mexicans are those who spend more time at work (paid and unpaid). On average, "...Mexicans work almost 10 hours a day (in formal jobs) in comparison with other countries that hold an average of just over 8 hours..." (OECD, 2013, p. 8). Additionally according to this study, after Mexico follows Japan, Portugal and Canada as the countries that work more hours per year. Of which, Portugal and Mexico have the lowest rates of paid work. This means that even when they spend many hours labor only half of the time is paid.

Goicoechea says (2004, p. 150) that "the disproportionate levels of job dedication affect the individual's daily behavior and affect their psychological balance, causing changes in health and work performance", psychosocial risks are seriously damaging individuals and organizations, affecting the health of the workers, breaking the internal cohesion of organizations, increasing mistrust and breaking the teamwork, causing phenomena such as violence, occupational stress, workplace harassment, sexual harassment and the so called "Burnout", subject of this article. According to Marrau $(2004$, p. 2$)$ "from a psychosocial perspective, this syndrome is conceptualized as a process that involves cognitive-aptitude variables (low personal accomplishment at work), emotional variables (emotional exhaustion) and attitudinal variables (depersonalization)". 
The professions related to healthcare, education and public administration are often the ones with the highest impact reflected in the statistics because they are in touch with people, with problems and they are usually the ones in charge of solving them. Frustration occurs when they realize that their work is not productive and feel that their job is barren. According to data between $20 \%$ and $30 \%$ of doctors, teachers and local police suffer from these symptoms (Boyle, et al., 1991). Other authors as (Ferrer, 2004; Vallejo, 2004) based on their research agree that the phenomenon is recurrent in workers that provide care for people (health, education, social workers, public administration, police, social services, advocacy, among others) due to working conditions that have strong social demands.

Many studies have shown that working conditions can cause adverse consequences in health and physical and psychological wellbeing of employees (Schaufeli \& Van Dierendonck, 1993; Cumming \& Cooper, 1998; Schaufeli \& Enzmann, 1998). These consequences have been identified as "burnout", a kind of stress related to welfare professions or services. Although in its first conceptualization the syndrome had three dimensions: low personal accomplishment, high emotional exhaustion and high depersonalization, in later studies it has been considered that the core of the phenomenon lies in the first two. Moreover, in recent decades theoretical models have been developed that seek to highlight certain patterns of causal relationships, thus trying to integrate the causing variables of "work-stress" with their results. Among all of them, the model developed by (Janssen, et al., 1999) specifies the predictive variables and its consequences while formulating a pattern of precise relationships between each other. This model is corroborated in subsequent studies through multimuestral analysis (Houkes, et al., 2001). The research on the phenomenon has allowed researchers to propose various studies and models. The bibliographical review allowed to locate 174 models/instruments, among which, using citation as filter and confirming that the instrument was validated, entail to bring together those most significant.

This article is organized as follows: Initially it describes the evolution of the concept of "Burnout" through time, Burnout models, which are divided into two types models: Comprehensive models and process models; Identification of the variables of the models and area of application, analysis and description of the models, critique of the models and description of the kind of research carried out in the Higher Educations Institutions of Mexico.

\section{Literature Review: Evolution of the "Burnout" Concept}

The bibliographical review identified 1974 as the year in which begins the study of this phenomenon and Herbert Freudenberger as the author of the beginning of these studies, however (Corcoran, 1985) states that Freudenberger illustrated "burnout" in 1971. Other authors such as Walker (1986, p. 36) accepted the study of the phenomenon by Freudenberger but established "that Graham Greene had already used it 1960 to describe a state of existential emptiness felt when a person had an incurable disease". On the other hand, (Starrin, et al., 1990) established the use of the term to describe the chronic effects of drug abuse. The authors (Freudenberger, 1974; Garcés, 1994; Mingote, 1998; Ramos, 1999; Buendía \& Ramos, 2001; Ponce, et al., 2005; Martínez, 2010) considered that people with Burnout develop hostile attitudes and behaviors, also intolerance and aggressiveness.

Years later, in 1977 Christina Maslach, recognized as an expert, presented the concept to the American Psychological Association (APA). Maslach (cited in Alvarez \& Fernandez, 1991, p. 257) used this term to refer to a "situation increasingly common among human service workers that, after months or years of dedication, end up burning metaphorically". On the other hand Salanova \& Schaufeli (2004, p. 75) argue that the "Burnout" refers to "a state of exhaustion in which high expectations, vitality and energy of the worker are ending, similar to a fire that suffocates, a candle been extinguished, a battery that runs out". Continuing the metaphor, Maslach (2009, p. 37) argues that "the fire of the initial enthusiasm, dedication and commitment to success has been "burned" (Burned out), leaving behind smoking coals of exhaustion, cynicism and inefficacy" (dimensions that give identity).

Gil-Monte says (2003a, p.182) that "when a worker is burned usually means that he is not satisfied in his work", this situation affects relationships with co-workers and service users and hostile behaviors emerge as well as physical and mental exhaustion, detachment with colleagues and service users, behaviors which, if not treated, may become chronic, according to (Ferrer, 2004, p. 99) "leading to increased consumption of alcohol, drugs, coffee, tea, snuff, stimulants and tranquilizers with wide repercussions on health". Ponce, et al., (2005, p. 89) considers that "two-thirds of occupational diseases have their origin or are related to this phenomenon, in addition to a decrease in the quality and promote the appearance of feelings of professional dissatisfaction". In recent years Maslach (2009, p. 37) reports that "burnout has become a popular way of describing the personal agony of work stress". Table 1 summarizes the conceptual evolution that the "Burnout" has had and the different definitions that different authors have given. 
Table 1. Authors and Burnout syndrome definitions

\begin{tabular}{|c|c|c|}
\hline Author & Year & Definition \\
\hline Freudenberger & 1974 & $\begin{array}{l}\text { A set of medical-biological and psychosocial nonspecific symptoms, that develop in the } \\
\text { work activity as a result of excessive demand of energy. }\end{array}$ \\
\hline Maslach \& Pines & 1977 & $\begin{array}{l}\text { It's the laboral exhaustion of the people who work in different sectors of human services, } \\
\text { always in direct contact with users, especially health personnel and teachers. The syndrome } \\
\text { would be the extreme response to chronic stress originated in the labor context and would } \\
\text { impact on an individual but also affect organizational and social aspects. }\end{array}$ \\
\hline Edelwich \& Brodsky & 1980 & $\begin{array}{l}\text { A process of disillusionment or disenchantment by labor activity, considering that the } \\
\text { development of enthusiasm, energy and unrealistic expectations can be the first stage to } \\
\text { wear out. }\end{array}$ \\
\hline Maslach \& Jackson & 1981 & $\begin{array}{l}\text { A behavioral manifestation of stress at work understood as a tridimensional syndrome } \\
\text { characterized by emotional exhaustion (EC), depersonalization (DP) in dealing with users } \\
\text { and customers and difficulty for achievement / fulfillment (RP). }\end{array}$ \\
\hline Perlman \& Hartman & 1982 & $\begin{array}{l}\text { A response to chronic emotional stress with three components: emotional and/or physical } \\
\text { exhaustion, low labor productivity and an excess of depersonalization. }\end{array}$ \\
\hline Pines \& Kafry & 1982 & $\begin{array}{l}\text { A chronic state of emotional exhaustion as a result of excessive involvement with people } \\
\text { over long periods of time. }\end{array}$ \\
\hline Burke & 1987 & $\begin{array}{l}\text { An adaptation process of laboral stress, characterized by professional disorientation, wear, } \\
\text { guilt feelings about lack of professional success, coldness or emotional detachment and } \\
\text { isolation. }\end{array}$ \\
\hline Maslach & 1993 & $\begin{array}{l}\text { A psychological syndrome of emotional exhaustion, depersonalization and reduced } \\
\text { personal accomplishment that can occur in normal individuals who work with people in } \\
\text { some way. }\end{array}$ \\
\hline Schaufeli \& Enzmann & 1998 & $\begin{array}{l}\text { Persistent mental state, negative and work-related, in 'normal' individuals that are primarily } \\
\text { characterized by exhaustion, which is accompanied by discomfort, reduced feelings of } \\
\text { competence and motivation and the development of dysfunctional attitudes at work. }\end{array}$ \\
\hline Gil-Monte \& Peiró & 1999 & $\begin{array}{l}\text { A chronic work stress response that leads to the experience of being emotionally drained } \\
\text { the development of negative attitudes and feelings towards workmates (depersonalization } \\
\text { attitudes) and the appearance of devaluation processes of its own professional role. }\end{array}$ \\
\hline Farber & 2000 & $\begin{array}{l}\text { A reflection of the majority of current work environments, since job competition demands } \\
\text { trying to produce more and better results in less time and with minimum resources. }\end{array}$ \\
\hline Maslach, Schaufeli \& Leiter & 2001 & $\begin{array}{l}\text { A prolonged response to chronic stressors on a personal and relational level with work, } \\
\text { determined from the known dimensions as exhaustion, depersonalization, cynicism, and } \\
\text { professional inefficacy. }\end{array}$ \\
\hline Schaufeli \& Buunk & 2003 & $\begin{array}{l}\text { It is the result of the discrepancy between expectations and individual ideals and, on the } \\
\text { other hand, the harsh reality of daily professional life. }\end{array}$ \\
\hline Gil-Monte & 2003 & $\begin{array}{l}\text { A chronic work stress response characterized by the tendency of professionals to negatively } \\
\text { evaluate their ability to perform the job and to relate with people they serve, for the feeling } \\
\text { of being emotionally exhausted, by the development of negative feelings, cynical behaviors } \\
\text { and attitudes towards work recipients which are seen in a dehumanized way due to affective } \\
\text { hardening of the professional. }\end{array}$ \\
\hline
\end{tabular}

Source: Based on information from the authors.

As noted, the concept has evolved from analyzing medical-biological and psychosocial nonspecific symptoms (Freudenberger, 1974), consider it as a process of disillusionment or disenchantment with work activity (Edelwich \& Brodsky, 1980) until exhaustion, which is accompanied by discomfort, a feeling of reduced competition and motivation and the development of dysfunctional attitudes at work (Schaufeli \& Enzmann, 1998) to hold negative feelings towards colleagues and the appearance of devaluation processes for its own professional role (Gil-Monte \& Peiro, 1999b). 
From the definitions above we wish to highlight four main ideas: 1) Physical and psychological exhaustion 2) A disappointment and disillusionment process 3) Dysfunction for work and 4) Appearance of feelings of devaluation of the professional role. Therefore, burnout is an occupational disease whose symptoms are: physical and emotional exhaustion, disappointment and disillusionment, devaluation of the professional role and dysfunction in the workplace.

According to Maslach (2009, p. 37) "in the last 25 years a lot of researches have established that this phenomenon is not purely fictional, it also serves as an indicator of major alterations in the relationship of people with their jobs". When within the same organization different workers with burnout are included, hostile behaviors are exacerbated and distant conducts increase between peers and service users, therefore the consequences go beyond the individual level or local area where the work is developed and acquire a negative multiplier effect, for example: when there is an organization with a large number of workers (burned team) with burnout, there is an affectation to society as a unit, causing poor attention and poor service to service users, especially in societies with a significant number of occupationally worn workers; in the same sense, the authors, Olabarría, \& Mansilla (2007, p. 8) explain that "burned equipment's generate high costs and management problems to the institution because they have a high staff turnover, a strong absenteeism and sick leaves".

When there is "Burnout" in an organization it affects culture, organizational climate and its formal structure, causing changes in the behavior of workers and work teams. The effects and negative consequences on the organization can be seen in various countries in existing economic estimates, even on a national rate. For example, the American Institute of Stress calculates that workplace stress costs to the U.S. industry about 300,000 million dollars a year in absenteeism, health costs and programs to help workers manage stress, according to (Levi, 2003). A study made by the National Institute of Health and Safety at Work mentions that job stress is considered by the European Union as the second most common health problem and its annual cost has come to reach 20,000 million euros (Europa Press, 2007). It is important to mention that such spending can increase over time if work stress becomes chronic and leads to burnout, all of this, if organizations do not establish strategies for prevention, intervention and/or confrontation for resolution.

Goicoechea (2004, pp. 151-152) sees the emergence of Burnout does not occur spontaneously, "it is rather a cyclical process that can be repeated several times over time, so that a person can experience the phenomenon at different periods of their life and in the same or in a different job". Alvarez \& Fernandez (1991) had reached similar conclusions in their research indicating that its apparition emerges gradually, hidden even, with a progressive increase in severity. In a first phase Manzano (2001, p. 148) points out that "many workers when starting their careers are full of enthusiasm and eager to give everything but the passage of time eventually leads to cynicism, frustration and emotional exhaustion". While, for Marrau (2009, p. 170) "the first evidence of burnout includes fatigue, depression, sleep disorders and appetite changes"; (Marrau 2009, p. 171) "The second phase is dissatisfaction, the loss of happiness and pleasure on what is being done". In a third phase toxic habits are acquired (alcohol, cigarettes, coffee) and if there is no a solution, usually arise feelings of abandonment, which ultimately result in the disturbance of the closest social relationship, that is marriage and family. As noted, the effects are severe, therefore the importance of quantification.

\section{Models of Burnout}

Is worth mentioning that there are several ways to classify the models of quantification of the phenomenon. From the psychoanalytic theory, it can be indicate that the main explanatory models of burnout are found in social psychology, Napione (2008) being these: Ecological model of human development, Decompensation model of assessment-task-demand, Sociological model, Oppression-demographic model, Social competency model. Other authors categorized explanatory models of this syndrome as comprehensive models and process models (Merodio, 2003; El Sahili \& Ali, 2010; El Sahili \& Ali, 2011). The following table number 2 sets the most quoted development models in literature and the authors who have postulate or adopted them on their studies and researches. 
Table 2. Burnout development models

\begin{tabular}{|c|c|c|}
\hline \multicolumn{3}{|c|}{ COMPREHENSIVE MODELS } \\
\hline Models & Representatives & Description \\
\hline $\begin{array}{l}\text { Models developed } \\
\text { from the cognitive } \\
\text { social theory of "the } \\
\text { self" }\end{array}$ & $\begin{array}{l}\text { - } \quad \text { The Chernis's model (1993) } \\
\text { - The model of self-control by } \\
\text { Thompson, Page \& Cooper (1993) }\end{array}$ & $\begin{array}{l}\text { It is inspired by the works of Albert Bandura, analyzes the } \\
\text { psychological mechanisms involved in the determination of the } \\
\text { action as the role of self-referential thought in human functioning. }\end{array}$ \\
\hline $\begin{array}{l}\text { Models developed } \\
\text { from the theories of } \\
\text { social exchange. }\end{array}$ & $\begin{array}{ll}\text { - } & \text { Buunk \& Schaufeli (1993) } \\
\text { - } & \text { Hobfoll \& Freddy (1993) }\end{array}$ & They consider the theoretical principles of equity theory. \\
\hline $\begin{array}{l}\text { Models developed } \\
\text { from organizational } \\
\text { theory. }\end{array}$ & $\begin{array}{l}\text { - The model of Golembiewski, } \\
\text { Munzenrider \& Carter (1983) } \\
\text { - The model of Cox, Kuk \& Leiter } \\
\text { (1993) } \\
\text { - Winnubst model (1993) }\end{array}$ & $\begin{array}{l}\text { They have in common an emphasis on contextual stressors of the } \\
\text { organization and of the strategies for coping with the experience of } \\
\text { getting burned by work. All of them consider Burnout as a } \\
\text { response to job stress. }\end{array}$ \\
\hline
\end{tabular}

\section{PROCESS MODELS}

\begin{tabular}{|c|c|c|}
\hline Models & Representatives & Description \\
\hline $\begin{array}{l}\text { Three-dimensional } \\
\text { models of the } \\
\text { MBI-HSS. }\end{array}$ & $\begin{array}{ll}\text { - } & \text { Maslach (1982) } \\
\text { - } & \text { The model of Golembiewski, } \\
\text { - } & \text { Munzenrider \& Carter (1983) } \\
\text { - } & \text { Lee \& Ashforth (1993) } \\
\text { - } & \text { Gil-Monte (1994) }\end{array}$ & $\begin{array}{l}\text { Considers the cognitive aspects (generally considered as } \\
\text { dimensions) these are (reduced personal accomplishment), } \\
\text { (emotional exhaustion) and attitudinal (depersonalization). }\end{array}$ \\
\hline $\begin{array}{l}\text { Edelwich \& Brodsky } \\
\text { model. }\end{array}$ & - $\quad$ Edelwich \& Brodsky (1980) & $\begin{array}{l}\text { Burnout is a process of disillusionment or disenchantment with } \\
\text { labor activity that occurs in a four-step process: } 1 \text {. Enthusiasm, } 2 . \\
\text { Stagnation, 3. Frustration, 4. Apathy (considered as a defense } \\
\text { mechanism against frustration). }\end{array}$ \\
\hline $\begin{array}{lll}\text { Price } & \& & \text { Murphy } \\
\text { model. } & & \end{array}$ & - $\quad$ Price \& Murphy (1984) & $\begin{array}{l}\text { Burnout is a process of adaptation to situations of labor stress, } \\
\text { occurs in six symptomatic phases: } 1 \text {. Disorientation, } 2 \text {. Emotional } \\
\text { labiality, } 3 \text {. Guilt due to professional failure, } 4 \text {. Loneliness and } \\
\text { sadness that, if overcome, may lead to the next phase, } 5 \text {. Request } \\
\text { for help, and } 6 \text {. Balance. }\end{array}$ \\
\hline Gil-Monte model. & - $\quad$ Gil Monte (2005) & $\begin{array}{l}\text { Distinguishes two profiles in the process of burnout: Profile } 1 \text {. It is } \\
\text { characterized by the presence of low enthusiasm for the job, along } \\
\text { with high levels of psychological exhaustion and indolence but } \\
\text { individuals do not show feelings of guilt. Profile } 2 \text {. It is often a } \\
\text { more serious problem that would allow identifying the most } \\
\text { damaged clinical cases by the development of burnout. In addition } \\
\text { to the symptoms above, individuals also have feelings of guilt. } \\
\text { These symptoms can be evaluated by the "Questionnaire for the } \\
\text { assessment of burnout syndrome by labor" (CESQT in Spanish). }\end{array}$ \\
\hline
\end{tabular}

Source: Quinceno \& Vinaccia (2007). Burnout "Síndrome de Quemarse en el Trabajo (SQT)" Acta Colombiana de Psicología, p. 122.

In general, the models shown are the ones that synthesize the vast majority of existing postures regarding the development and emergence of burnout, it is important to take into account the different quantification instruments that have been developed. Below is Table 3 where it can be observed the authors who have proposed them, the year in which were presented to the scientific community, the used variables and the main areas for which they were developed. Their inclusion is because of the 174 instruments located, only 21 have the author's recognition by the Science Citation Index, in addition to statistical validity. 
Table 3. Burnout quantification instruments

\begin{tabular}{|c|c|c|c|}
\hline Authors & Name of the Instrument & Variables & Area to be used \\
\hline Jones (1980) & $\begin{array}{l}\text { Staff Burnout Scale for } \\
\text { Health } \quad \text { Professionals } \\
\text { (SBS-HP) }\end{array}$ & $\begin{array}{l}\text { - } \text { Dissatisfaction at work, } \\
\text { - Psychological and interpersonal tension, } \\
\text { - Negative consequences of stress, } \\
\text { - Non professional relationships with patients. }\end{array}$ & Health. \\
\hline Gillespie (1980) & Burnout Indicators. & $\begin{array}{l}\text { - } \text { Provide worth while services } \\
\text { - } \text { Avoid difficulties with clients } \\
\text { - Getting angry with kindways } \\
\text { - } \text { Customer self-separation } \\
\text { - Prefering the field instead of the office } \\
\text { - Jokin gab out customers continuously } \\
\text { - } \quad \text { Being absent several days for mental health reasons }\end{array}$ & $\begin{array}{l}\text { Welfare } \\
\text { professions in } \\
\text { general. }\end{array}$ \\
\hline $\begin{array}{l}\text { Emener \& Luck } \\
(1980)\end{array}$ & $\begin{array}{l}\text { Emener-Luck Burnout Scale } \\
\text { (ELBOS) }\end{array}$ & $\begin{array}{l}\text { - } \text { General Labor-Related Sensations } \\
\text { - Work-related and with himself feelings } \\
\text { - Work- Preparation of theEnvironment } \\
\text { - Negative responses of people within the environment } \\
\text { - Dissonance } \\
\text { - Self-concept versus others self-concepts }\end{array}$ & Educational \\
\hline $\begin{array}{l}\text { Pines, Aronson \& } \\
\text { Kafry (1981) }\end{array}$ & Tedium Measure & $\begin{array}{l}\text { - } \text { Feelings of depression } \\
\text { - Burnout } \\
\text { - Emotional and physicaltiredness } \\
\text { - Existential void } \\
\text { - Boredom } \\
\text { - Tension } \\
\text { - Feelings of ilusion and happiness }\end{array}$ & $\begin{array}{l}\text { Welfare } \\
\text { professions in } \\
\text { general. }\end{array}$ \\
\hline $\begin{array}{l}\text { Kremer \& Hofman } \\
\text { (1985) }\end{array}$ & Burnout Scale & $\begin{array}{l}\text { - The items were not subjected to factorial analysis, } \\
\text { therefore it is unknown if they really analyze the } \\
\text { Burnout. }\end{array}$ & - \\
\hline $\begin{array}{l}\text { Maslach \& Jackson } \\
\text { (1986) }\end{array}$ & $\begin{array}{l}\text { Maslach Burnout Inventory } \\
\text { (MBI) }\end{array}$ & $\begin{array}{l}\text { - } \text { Emotional Exhaustion } \\
\text { - Depersonalization } \\
\text { - } \quad \text { Low personal accomplishment }\end{array}$ & Health \\
\hline $\begin{array}{l}\text { Seidman } \& \text { Zager } \\
\text { (1986) }\end{array}$ & Teacher Burnout Scale & $\begin{array}{l}\text { - } \\
\text { - } \text { Satisfaction with the profession } \\
\text { - Attitude stoward students } \\
\text { - Administrative support perceived }\end{array}$ & Educational \\
\hline Garden (1987) & Energy Depletion Index & $\begin{array}{l}\text { - Scale to evaluate the "Depletion of Energy" that } \\
\text { corresponds to the emotional exhaustion dimension } \\
\text { of Maslach and Jackson (1981) }\end{array}$ & \\
\hline $\begin{array}{lll}\text { Pines } & \& & \text { Aronson } \\
(1988) & & \end{array}$ & Burnout Measure (BM) & $\begin{array}{l}\text { - Physical exhaustion } \\
\text { - Emotional exhaustion }\end{array}$ & \\
\hline Mattews (1990) & $\begin{array}{l}\text { Mattews Burnout Scale for } \\
\text { Employees (MBSE) }\end{array}$ & $\begin{array}{l}\text { - } \\
\text { - Attitudes about work } \\
\text { - } \\
\text { - } \\
\text { - Pecus of cononal adjustment of role } \\
\end{array}$ & $\begin{array}{l}\text { Welfare } \\
\text { professions in } \\
\text { general. }\end{array}$ \\
\hline $\begin{array}{l}\text { García Izquierdo \& } \\
\text { Velandrino (1992) }\end{array}$ & $\begin{array}{l}\text { Scale of Psychic Effects of } \\
\text { Burnout }(E P B)\end{array}$ & $\begin{array}{l}\text { - } \quad \text { Negative attitud estoward work } \\
\text { - Negative expectation stoward work }\end{array}$ & $\begin{array}{l}\text { Welfare } \\
\text { professions in } \\
\text { general. }\end{array}$ \\
\hline $\begin{array}{ccc}\text { Aveni } & \& & \text { Albani } \\
(1992) & & \end{array}$ & $\begin{array}{l}\text { Scale of Predicting } \\
\text { Variables of Burnout } \\
(\text { EVPB })\end{array}$ & $\begin{array}{l}\text { - Anxiety } \\
\text { - } \text { Depression }\end{array}$ & $\begin{array}{l}\text { Welfare } \\
\text { professions in } \\
\text { general. }\end{array}$ \\
\hline
\end{tabular}




\begin{tabular}{|c|c|c|c|}
\hline $\begin{array}{l}\text { Moreno-Jiménez, } \\
\text { Oliver \& Aragoneses } \\
\text { (1993) }\end{array}$ & $\begin{array}{l}\text { Burnout questionnaire for } \\
\text { the teaching staff }(C B P)\end{array}$ & $\begin{array}{ll}\text { - } & \text { User-blaming } \\
\text { - } & \text { Isolation } \\
\text { - } & \text { Interpersonal distance } \\
\text { - } & \text { Emotional hardening } \\
\text { - } & \text { Dehumanised self-defense } \\
\text { - } & \text { Negative change in attitudes towards users } \\
\text { - } & \text { Irritability with theusers }\end{array}$ & Educational \\
\hline $\begin{array}{l}\text { Holland \& Michael } \\
\text { (1993) }\end{array}$ & $\begin{array}{l}\text { Holland Burnout } \\
\text { Assessment Survey }(\text { HBAS) }\end{array}$ & $\begin{array}{l}\text { - } \text { Positive perception of teaching } \\
\text { - } \text { Commitmentto teaching } \\
\text { - } \quad \text { Support from supervisors } \\
\text { - } \quad \text { Knowledge of Burnout }\end{array}$ & Educational \\
\hline $\begin{array}{l}\text { Dell'Erba, Venturi, } \\
\text { Rizzo, Porcus \& } \\
\text { Pancheri (1994) }\end{array}$ & $\begin{array}{l}\text { Rome Burnout Inventory } \\
(R B I)\end{array}$ & 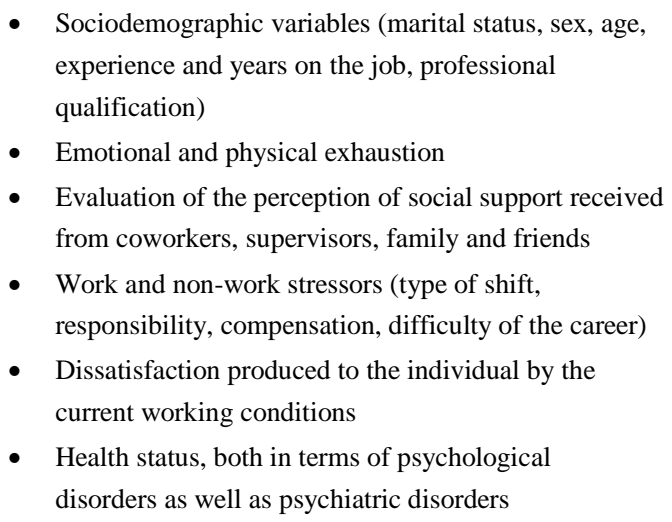 & $\begin{array}{l}\text { Welfare } \\
\text { professions in } \\
\text { general. }\end{array}$ \\
\hline Friedman (1995) & $\begin{array}{l}\text { Burnout Scale for School's } \\
\text { Principals }\end{array}$ & $\begin{array}{l}\text { Exhaustion (describes feelings of emotional } \\
\text { exhaustion, physical and cognitive) } \\
\text { - } \text { Reserve (explains the detachment by the teacher with } \\
\text { everyday problems, with new ideas) } \\
\text { - Contempt (refers to negative feelings of contempt } \\
\text { towards teachers, students and parents) }\end{array}$ & Educational \\
\hline $\begin{array}{l}\text { Schaufeli, } \quad \text { Leiter, } \\
\text { Maslach \& Jackson } \\
\text { (1996) }\end{array}$ & $\begin{array}{lr}\text { Maslach } & \text { Burnout } \\
\text { Inventory-General } & \text { Survey } \\
(\text { MBI-GS }) & \end{array}$ & $\begin{array}{l}\text { - } \text { Professional effectiveness } \\
\text { - } \text { Exhaustion } \\
\text { - } \text { Cynicism }\end{array}$ & $\begin{array}{l}\text { Welfare } \\
\text { professions in } \\
\text { general. }\end{array}$ \\
\hline $\begin{array}{l}\text { Moreno-Jiménez } \\
\text { Bustos, Matallana \& } \\
\text { Millares (1997) }\end{array}$ & $\begin{array}{ll}\text { Burnout } & \text { Brief } \\
\text { Questionnaire }(C B B) & \end{array}$ & $\begin{array}{ll}\text { - } & \text { Taskcharacteristics } \\
\text { - } & \text { Organization } \\
\text { - } & \text { Boredom } \\
\text { - } & \text { Emotionalexhaustion } \\
\text { - } & \text { Depersonalization } \\
\text { - } & \text { Personal realization } \\
\text { - } & \text { Physical, social and psychological consequents }\end{array}$ & $\begin{array}{l}\text { Welfare } \\
\text { professions in } \\
\text { general. }\end{array}$ \\
\hline $\begin{array}{l}\text { Moreno-Jiménez } \\
\text { Garrosa, \& González } \\
\text { (2000) }\end{array}$ & $\begin{array}{l}\text { Questionnaire for burnout } \\
\text { in nursing (CDPE) }\end{array}$ & $\begin{array}{l}\text { - } \text { Background } \\
\text { - } \text { Professional Wear } \\
\text { - } \text { Resistant Personality } \\
\text { - } \text { Confrontation } \\
\text { - } \text { Consequences }\end{array}$ & Health \\
\hline Gil-Monte (2005) & $\begin{array}{l}\text { Assessment Questions for } \\
\text { Burnout Syndrome at Work } \\
\text { (CESQT) }\end{array}$ & $\begin{array}{l}\text { - } \text { Illusion for the job } \\
\text { - } \text { Psychic wear } \\
\text { - Indolence } \\
\text { - } \quad \text { Guilt }\end{array}$ & $\begin{array}{l}\text { Welfare } \\
\text { professions in } \\
\text { general. }\end{array}$ \\
\hline $\begin{array}{l}\text { Moreno-Jiménez, } \\
\text { Macarena, Herrera, } \\
\text { Hernández \& } \\
\text { Mingote (2006) }\end{array}$ & $\begin{array}{l}\text { Scale of the medical } \\
\text { professional wear syndrome } \\
\text { pertaining to the medical } \\
\text { professional wear } \\
\text { questionnaire (CDPM). }\end{array}$ & $\begin{array}{l}\text { - Exhaustion } \\
\text { - } \quad \text { Distancing and loss of expectation }\end{array}$ & Health \\
\hline
\end{tabular}

Source: Own elaboration with information of the mentioned authors. 


\section{Analysis and Description of the Quantification Instruments}

The analysis of the instruments and their variables suggests that the most consistent dimension of the border authors considered that the key dimension in the quantification of phenomenon is emotional exhaustion, also identified with other names such as emotional drain and emotional fatigue. Researchers who have used it in their instruments are: (Jones, 1980; Gillespie, 1980; Pines, et al., 1981; Maslach \& Jackson, 1981; Schwab, 1986; Hock, 1988; Moreno-Jiménez, et al., 1993; Dell'Erba, et al., 1994; Friedman, 1995; Schaufeli, et al., 1996; Moreno-Jimenez, et al., 1997; Moreno-Jimenez et al., 2000; Benavides et al., 2002; Gil-Monte, 2005).

The second variable is the cynicism (CI) or depersonalization. The authors that have considered it as a significant dimension on their instruments are: (Jones, 1980; Gillespie, 1980; Emener-Luck, 1980; Maslach \& Jackson, 1981; Seidman \& Zager, 1986; Schwab, 1986; García-Izquierdo \& Velandrino, 1992; Moreno-Jimenez, et al., 1993; Dell'Erba, et al., 1994; Friedman, 1995; Schaufeli, et al., 1996; Moreno-Jimenez, et al., 1997; Benavides et al., 2002; Gil-Monte 2005).

The third variable, inefficiency (IN), has been considered in their instruments for the following authors: (Jones, 1980; Emener \& Luck, 1980; Petegrew \& Wolf, 1981; Maslach \& Jackson, 1981; Farber, 1984; Seidman \& Zager, 1986; Schwab, 1986; García-Izquierdo \& Velandrino, 1992; Moreno-Jimenez, et al., 1993; Holland \& Michael, 1993; Dell`Erba, et al., 1994; Schaufeli, et al., 1996; Moreno-Jimenez, et al., 1997).

Certainly it was then observed that some variables such as feelings of guilt, proposed by Gil-Monte (2005) in his instrument entitled "Questionnaire for the Assessment of Burnout Syndrome by Work (CESQT)" need more evidence in order to be considered as a significant variable that must be inserted on the quantification of the burnout (Benavides, et al., 2002). Another point to mention is that many very unique models use variables that are related to specific contexts.

The analysis of the instruments took as filters the use of the instruments, the belonging to a frontier author and a proven validity of the instrument. With these characteristics we can quote the following:

The Staff Burnout Scale for Health Professional (SBS) of Jones (1980). Conformed by 20 items with Likert response that evaluates the burnout, the scale can be divided into four factors: job dissatisfaction, psychological and interpersonal tension, and negative consequences of stress and nonprofessional relationships with patients. The instrument was designed for health professionals, although it can be applied to other professions. The reliability reported is (0.79) and correlations found with emotional exhaustion and depersonalizations of the MBI are quite acceptable, while using personal accomplishment scale, the correlation is low (Guerrero \& Vicente, 2001). Authors like (Leiter, et al., 1996; Moreno-Jimenez, et al., 1997) have used it on their researches.

Tedium Scales (TS) of Pines, Aranson and Kafry (1981). Consists of 21 items that use as variablesfeelings of depression, burnout, emotional and physical exhaustion, existential emptiness, boredom, tension, feelings of hope and happiness, all of them evaluated with a Likert response of seven points. One of the problems of this questionnaire is that it has no explicit association with the work context. The measure of boredom compared with MBI indicates that the reliability of the first is slightly higher, but is more recommendable to use the second. Validity values are relatively low, ranging between 0.6 and 0.7 . The instrument is criticized on the fieldwork conducted by (Moreno-Jimenez, et al., 1997; Benavides et al., 2002; Gil-Monte, 2005).

The Gillespie-Numer burnout inventory (GNBI) (1979), (1980). When the study of the Gillespie phenomenon began, a problem of absence of measures was detected and, as a result, the author designed an instrument with 7 potential indicators shaped as items with a Likert kind response option, the validity obtained was of 0.78 used in a sample of 183 subjects. The indicators were: proportion of worthwhile services, the avoidance of difficulties with clients, getting angry with the kind manners, self-separation from customers, choosing office work over field work, continuous jokes about customers and absenteeism due to mental health. The author, based on statistical analysis, concludes that the phenomenon is a multidimensional construct characterized by the previously named indicators; according to type of burnout presented, being an active burnout (makes reference to organizational factors and is characterized by the hardening with kind manners) or the passive burnout (relates to internal psychosocial factors and is characterized by separation of clients and to prefer office work instead of field work). Authors like, (García-Izquierdo \& Velandrino, 1992; Moreno-Jimenez, et al., 1993; Holland \& Michael, 1993) confirm their validity.

Emener-Luck Burnout Scale (ELBOS) (1980). The authors begin with three objectives in the design of their instrument, being these: Achieving a scale that would allow quantifying the burnout, to provide a stimulus for discussion of the syndrome in a groupal and individual way and to enable an instrument that would serve decision makers in the prevention and confrontation of the phenomenon. The indicators used were: work 
general-related sensations, sensations related to work and with the "own self", work-preparation of the environment, negative responses of people within the environment, dissonance and self-concept versus other self-concepts. Of the 100 items used at the beginning the instrument, 30 were retained and applied to a sample of 251 teachers, using a nine-point bipolar scale from "never" to "always" with a validity of 0.877 . The scale has been used in several studies by researchers as (Petegrew \& Wolf, 1981; Dell'Erba, et al., 1994; Friedman, 1995).

Tedium Burnout Measure (BM) of Pines, Aronson \& Kafry (1981). This instrument was initially originated as an instrument for measuring tedium, since the authors believe that the concept is wider than the "burnout". Later it transformed into the Burnout Measure (Pines \& Aronson, 1988) from a conceptual rethinking. Initially, the authors had developed various scales for tedium (Pines \& Kafry, 1982) with 9 items with seven Likert response options, using the following indicators: feelings of depression, burnout, emotional and physical exhaustion, existential emptiness, tedium, stress and feelings of excitement and happiness. In 1988, the Burnout Measure (BM) is designed with 21 items to measure three dimensions which were: physical exhaustion (characterized by fatigue, physical exhaustion and feeling of destruction and gloom), emotional exhaustion (feeling composed by depression, emotional exhaustion and burnout) and mental exhaustion (formed by feelings of unhappiness, worthlessness and rejection, lack of enthusiasm and resentment towards people). Its validity was taken from the latter with a score of 0.81. The last instrument has been used by (Farber, 1983; Farber, 1984; Seidman \& Zager, 1986; Schwab 1986).

Burnout Scale of Kremer \& Hofman (1985). The instrument was originated as a result of studying the phenomenon of burnout in a wider investigation. The authors propose 5 items, which by way of a self-report, are included in a more ambitious instrument for measuring other constructs. These items are subjected to factorial analysis, therefore it is unknown if they really analyze the "burnout", if they do unidirectional or if, on the contrary, their items are distributed on one more factor, the only information they offer is reliability $\mathrm{a}=0.54$. Authors like (Moreno-Jiménez, et al., 2000; Benavides et al., 2002; Gil-Monte, 2005) made a negative review of it.

Maslach Burnout Inventory (MBI) of Maslach and Jackson (1986). It is the most used among researchers, consists of 22 items in the form of statements about the feelings and attitudes of the professional in their work and towards clients. Assesses: emotional exhaustion, depersonalization and reduced personal accomplishment at work.Considers the "burnout" as a continuous variable that can be experienced at different levels and not as a dichotomous variable. This scale is the one that has demonstrated greater validity and reliability (between 0.75 and 0.90). However, recent studies show reviews and reflections about the concept and dimensionality of "burnout" that directly affect the consequences of the MBI as the appropriate instrument of measurement (Dell'Erba, 1994; Schaufeli, et al., 1996; Moreno, et al., 1997; Barnett, et al., 1999; Benavides et al., 2002; Gil-Monte 2005; Garcia, et al., 2007) in addition, two weaknesses of the instrument are pointed out: the items that describe feelings are not direct and response categories are not mutually exclusive.

In Spain, this scale has been validated in diverse samples for its adaptation, among the authors who have used it are: Moreno-Jiménez, et al., (2002) who conducted a study on a sample of 235 subjects obtaining as a result that the evaluated independent variables were discriminative in the three existing dimensions, although stating that the depersonalization scale was underrepresented on the number of items. Gil-Monte \& Peiro $(1998,2000)$ applied the MBI in a sample of 559 professionals from various occupations; they performed a factorial analysis of the three scales and showed an adequate validity and reliability of the Castilian-adapted version. Garcia et al., (1995) used an adaptation of the MBI in the sports field in a sample of 256 athletes and after a factorial analysis, confirmed that it was a sensitive measuring instrument. Currently there are three versions of the MBI. The MBI-Human Services Survey (MBI-HSS) is the classic version of the MBI and is constituted by three scales of the dimensions described by its authors, addressed to health professionals. The MBI Educators Survey (MBI-ES) is the version for education professionals where the word "patient" is changed to "student" and finally the MBI-General Survey (MBI-GS) that has a more generic nature since it is not exclusive to any professional type, maintains the three-dimensional structure of the MBI but only contains 16 of the 22 initial items. Moreno-Jiménez et al., (2006) analyzed the MBI-General Survey in a sample of 114 subjects and found that the psychometric characteristics are highly satisfactory and correspond exactly with the theoretical model presented by their authors. Gil-Monte (2004) analyzed the factorial structure in the Castilian adaptation on a sample of 149 police officers and concluded that the questionnaire can be valid and reliable on the Castilian adapted version.

Teacher Burnout Scale (TBS) of Seidman \& Zager (1986). The authors argue that although the MBI is an appropriate instrument to measure burnout in human service professions, it is not to specifically measure burnout in teachers (however, in that same year Maslach \& Jackson (1986), when introducing the second edition of the MBI, developed a version of the instrument specifically for these professionals). Following this premise, it is put 
to the test the Teacher Burnout Scale (TBS) which at its beginning was composed of 65 items on a Likert scale for a sample of 217 teachers, and then, after appropriate statistical analyzes, 23 items remained. Of those items, three were reformulated, another three new were introduced and re-administered to 365 teachers, leaving the final version in 21 items that account for $60 \%$ of the variance by four factors: Satisfaction with the Career, which correlates with a reduced personal accomplishment and has 5 items; Coping with Work related Stress, which is correlated with emotional exhaustion and is composed of 6 items; Attitudes toward students, which is correlated with depersonalization and has 4 items, and finally Perception of Support by the Supervisor, which does not correlate with any scale of MBI (Maslach Burnout Inventory) and has 6 items. The reliability of the TBS (Teacher Burnout Scale) ranges from 0.89 (career satisfaction) and 0.72 (attitudes towards students), thereby presenting an acceptable internal consistency (Schaufeli, et al., 1996; Moreno-Jiménez, et al., 1997; Moreno-Jiménez, et al., 2000).

Energy Depletion Index (EDI) of Garden (1987). Garden, on its instrument, questions the depersonalization dimension and aims to delve into the true characteristics of the burnout, which the author summed up in four main component factors. Specifically the scale consists of seven items that measure levels of energy or exhaustion. After the factorial analysis, two factors were found: "Energy" composed of four items with a reliability of 0.82 , while the second would be consisted by two items that would evaluate "Energetic Feelings and Enthusiasm". The study was able to demonstrate that its instrument measures the central dimension of burnout, which corresponds to emotional exhaustion; the above referenced by (García-Izquierdo \& Velandrino, 1992; Moreno-Jimenez, et al., 1993).

Matthews Burnout Scale for Employees (MBSE) of Matthews (1990). It is a self-report that measures burnout as a single construct without addressing the possibility of various dimensions that make up the syndrome. The scale provides a score that allows discriminating between the presence or absence of burnout, by analyzing a number of aspects related to cognitive variables and emotional and psychological needs of the individual. Introduces in his instrument four work-related aspects (attitudes about work, role adjustment, locus of control and coping skills) and another two internal variables related to the individual (personal adjustment and temperament). These features allow knowing which variables are determining the existence of burnout. It is an instrument with little use, although its 50 items showed a reliability index of around 0.93 . The instrument has been used by: (García-Izquierdo \& Velandrino 1992; Moreno, et al., 1993).

Scale of Predicting Variables of Burnout (EVPB) Aveni \& Albani (1992). It is not exactly a tool for measuring burnout, but arises as a result of a previous theoretical approach, which states that the predictors of burnout must maintain correlation with those found in other two constructs: anxiety and depression. The authors applied the scale to a sample of social workers, an inventory of anxiety and an inventory for depression, and the results obtained led to a set of variables that would be predictors of the phenomenon. Authors as (Moreno-Jimenez, et al., 1997; Benavides et al., 2002) give the scale unreliability.

Scale of Psychic Effects of Burnout (EPB) Garcia-Izquierdo \& Velandrino (1992). It is a Likert-type instrument, similar to others that measure the physical effects of burnout (Golembiewski, et al., 1984; Gillespie, \& Numerof, 1984; Hock, 1988). At various investigations in which this scale has been used (García-Izquierdo, 1991, 1995; García-Izquierdo \& Velandrino 1992, García-Izquierdo, et al., 1993) has shown a very adequate internal consistency with reliability coefficients higher than 0.90. García-Izquierdo, et al., (1994) find reliability of 0.92 in the EPB, appearing with only one stable factor, even though the instrument originally had two factors: Negative Attitudes towards Work (9 items) and Negative Expectations to Work (3 items), concluding that this scale correlates with the emotional exhaustion dimension of the MBI (Maslach Burnout Inventory).

Teaching Staff Burnout Questionnaire (CBP) of Moreno and Oliver (1993). The CBP was presented still in its experimental phase and it's a consequence of the theoretical approach that the authors had performed and shown by (Fernandez, et al., 1990; Oliver, et al., 1990; Moreno-Jiménez et al., 1991) these last had found that the scale of depersonalization didn't seemed sufficiently descriptive nor with a clear statistical independence. As a result of these previous studies, Moreno-Jiménez \& Oliver (1993) attempted to improve this dimension by building an exclusive depersonalization scale, which consists of 16 items that correspond to the following descriptors: user guilt, isolation, interpersonal distance, emotional hardening, dehumanized self-defense, negative change in attitudes towards users and irritability with users.

Holland Burnout Assessment Survey (HBAS) of Holland \& Michael (1993). The HBAS was introduced to test the concurrent validity of the questionnaire. This instrument, composed of 18 items with five response options, is constructed by four factors: positive perceptions of teaching, commitment to teaching support from the supervisors and knowledge of the burnout, this instrument is designed for teachers. That is why the authors 
contrasted this instrument with the ES version (Educators Survey) of the MBI (Maslach Burnout Inventory). In this analysis it is found a good behavior of the two sub-scales that measure the first two factors, same ones that, on the other hand, present reliability coefficients around 0.84 and behave less appropriate than the other two sub-scales (which measure the next two factors), which have reliability coefficients close to 0.62. (Soler, et al., 2008).

Rome Burnout Inventory (RBI) de Dell’Erba, Venturi, Rizzo, Porcus \& Pancheri, (1994); Venturi, Rizzo \& Dell'Erba, (2006). This instrument is divided into six sections: a first section gathers items that provide information on socio-demographic variables (age, sex, marital status, experience and years on the job, professional qualification, among others), a second block measures emotional and physical exhaustion, the third assesses the perception of social support received from co-workers, supervisors, friends and family, the fourth measures work and non-work stressors (type on shift, responsibility, compensation, career trouble, etc.) the fifth refers to the dissatisfaction that produces the individual's current working conditions, and finally, the sixth, a set of items that measure the health status, both in terms of psychological disorders and psychiatric disorders. The originality of the instrument lies in having managed to make a series of sub-tests that measure not only burnout (which they do according to the Burnout Measure of Pines and Aronson) (1988), but also those other constructs (job satisfaction) or predictor variables of the syndrome (social support or job stressors) that allow a more complete assessment.

Burnout Scale for School Principals of Friedman (1995). The author presents an instrument to assess burnout in school principals. To do this, he adapts the MBI items and applies them to a sample of 821 principals. He obtains the following factorial structure: Exhaustion ( 9 items), which describes feelings of emotional, physical and cognitive exhaustion, becoming evident the general decrease of energy in the person; Reserve (7 items), which explains the detachment that the teacher establishes with the everyday problems and with new ideas and suggestions, decreases enthusiasm, interest and support to teachers; Contempt (6 items), which refers to negative feelings of contempt towards teachers, students and parents. Some authors like: (Schaufeli, et al., 1996; Moreno-Jimenez, et al., 1997; Gil-Monte, et al., 2006; Tifner, et al., 2006), suggest that more research is needed to test the instrument, as it appears that the inventory is appropriate to measure burnout in school principals, in fact, as demonstrated by psychometric data: the coefficient alpha for the total scale is 0.92 (0.98 to Exhaustion, 0.82 for Reserved and 0.97 for Contempt). Also, the total variance explained is $46.3 \%$.

Burnout Brief Questionnaire (CBB)-Jimenez Moreno, Bustos, Matallana \& Miralles, (1997). The Burnout Brief Questionnaire (CBB) is designed with 21 items and seven scales: emotional exhaustion, depersonalization, reduced personal accomplishment, tedium, organizational climate, task characteristics and impact of burnout in the life of the subject; presenting an adequate convergent validity, according to its authors, of 0.897 . Authors like (Benavides, et al., 2002; Gil-Monte, 2005) state that there isn't a clear statistical independence.

Questionnaire of Professional Burnout in Nursing (CDPE) of Moreno-Jiménez, Garrosa, \& González (2000). The instrument was designed for the specific assessment of burnout in the nursing group. This questionnaire includes scales focused on the evaluation of the most relevant variables of the burnout process within this profession. The scale has factorial validity, internal consistency of its scales and existing structural interdependence between them. The questionnaire design was based on the analysis of existing theoretical information, the development of various semi-structured interviews and group discussions. After the application to a pilot sample of 30 people, the resulting questionnaire was answered by 389 nurses working in five hospitals in Madrid. A factorial analysis was performed for each of the blocks that integrate the questionnaire (background aspects, consequent, mediators and specifics of the Burnout syndrome) by the principal axes method and using an oblique rotation (direct obliging). The analysis of the internal consistency of the scales was based on the calculation of Cronbach's alpha coefficients. Finally, an analysis was conducted on the correlations between the scales of the different blocks to determine the degree of interdependence between them. CDPE analysis shows favorable results regarding its reliability and construct validity, however, Benavides et al., (2002) felt that it was necessary to develop new works that provide more information on the criteria for goodness of the instrument.

Questionnaire for Evaluating Burnout Syndrome by Work (CESQT) Gil-Monte (2005). This instrument contains 20 items divided into four dimensions: Illusion for work (5 items), Psychological exhaustion (4 items), Indolence (6 items) and Guilt (5 items). The theoretical model underlying the CESQT considers that cognitive impairment (low scores on Illusion for work) and emotional (high scores in psychological exhaustion) appear at first in response to chronic job stress sources, and later, individuals will develop negative attitudes towards the people they serve in their work (high levels of Indolence). The emergence of feelings of guilt comes after these symptoms, without appearing in all individuals. In this way, we can distinguish two profiles in the process of the SQT. 
The Profile 1 leads to the appearance of a set of feelings and behaviors related to job stress that cause a mild form of discomfort but do not incapacitate the individual for doing their job, although it could be done better. This profile is characterized by the presence of low illusion for the job, along with high levels of psychological exhaustion and indolence, but the individuals do not have feelings of guilt. Profile 2 is often a more serious problem that would identify the most damaged clinical cases by the development of burnout. In addition to the above symptoms individuals also have feelings of guilt (Gil-Monte, 2005). The instrument has been used by authors such as (Carmona-Monge, et al., 2002; Blandin \& Martinez, 2005; Aranda \& Torres, 2005; Barraza, 2006) to name a few.

Burnout Syndrome Scale for Medical Professional Burnout belonging to Medical Professional Burnout Questionnaire (CDPM) of Moreno, Macarena, Herrera, Hernández y Mingote (2006). It is a scale of 2 phases, where Phase I is composed of psychometric factors and phase II is based on the Maslach Burnout Inventory (MBI). For its validation two samples were used. For Phase I was utilized a community of Madrid formed by 485 doctors (primary care health centers and hospitals) and for Phase II a different sample of 100 doctors (primary care health centers). The exploratory and confirmatory factorial analysis of CDPM ratifies three descriptive factors of medical professional wear: exhaustion, detachment and loss of expectation, with acceptable internal consistency. Convergent validity was confirmed by the MBI, especially in the dimension of exhaustion. This scale provides the specific evaluation of the syndrome in the medical profession and should include motivational factors rather than professional inefficacy. The dimension "exhaustion" is defined as the primary descriptor of medical burnout in the sample. According to the new approaches, it provides an instrument that allows specific assessment of the dimensions of medical burnout and an overall evaluation of the syndrome.

\section{Critique to the Models and Quantification Instruments}

Of all the self-report instruments mentioned, the most widely used and that it has been the basis of the other instruments is the "Burnout Inventory" of Maslach \& Jackson (1986). There have been various criticisms about it, highlighting the following: focuses the statements on emotions and feelings, makes no reference to the conducts caused or eliminated when these emotions and feelings arise, some terms are not conceptually clear since its meaning can vary individually, the scale of low personal accomplishment has fewer items compared to the other two scales, do not disaggregate some statements in more direct behaviors and finally, it is a closed format that does not adjusts to the various conditions that can be created in the working environment, that possibly, maintains a situation of suffering on a person.

But despite the above, this model, and its instrument, is the one that has had a greater acceptance and success for its use in the quantification of Burnout. The instrument (backed at the same time by a three-dimensional theoretical model) has survived the test of time and has undergone several modifications and adaptations, situation that has given birth to the emergence of different versions and questionnaires that have been based on the "Maslach Burnout Inventory". One of the most significant findings in this study, is that this method of quantification, in its versions: Educators Survey, General Survey, Health Services Survey; is used in 90\% of studies worldwide (Schaufeli \& Enzmann, 1998) including Mexico and Spain.

Returning to the discussion of the main features and properties of the instrument, it was found that one of its main strengths that highlights is its international acceptance, however, authors such as (Olivares \& Gil-Monte, 2009) have found several weaknesses on the instrument, which calls into question the feasibility for its application in different contexts and study subjects, as it happens in countries like Mexico where specific measuring instruments are demanded, since both organizations and workers, display particular labor realities that are differentiated from those in other countries, where the instruments were created, as mentioned by Gil-Monte.

More and more countries are incorporating researches on the subject, such is the case of countries like Argentina, Brazil, Chile, Colombia, Mexico, Peru, Uruguay that require construction, design, tropicalization, adequacy and a proposal for measuring instruments and intervention models, that allow to adapt to their organizational and cultural characteristics, where there are different labor realities. Additionally, the absence of a commercial version of the MBI (instrument used to quantify the phenomenon) is making difficult its study in the Ibero-American world (Gil-Monte, 2004). Next, we analyze more specifically the characteristics, strengths and weaknesses of the MBI.

The authors García-Izquierdo \& Velandrino (1992) considered that the MBI (Maslach Burnout Inventory) is one of the most used scales to assess the frequency and intensity of Burnout, bringing together the three variables allegedly involved with the phenomenon, which are: emotional exhaustion, cynicism and inefficacy.

In the review of the phenomenon, made in the third edition of the MBI of Maslach, Jackson \& Leiter (cited in Moreno-Jiménez, et al., 2001) it is recommended to replace the variable named "depersonalization" with the 
variable named "cynicism", since this last one encompasses everything described above and includes aspects of self-criticism, devaluation, self-sabotage and disregard for their own work.

It is important to know that, when Burnout is quantified through the MBI, we can understand that it adopts a multidimensional vision of Burnout (Maslach, 1998). Those authors who have adopted this vision, argue that provides a holistic representation of a complex phenomenon; although in the opposite view, it is mentioned that is still necessary to provide convincing theoretical arguments about why the three different sets of symptoms that constitute its conceptualization should "be united", Maslach, Schaufeli \& Leiter (cited in Shirom, 2009). Moreover, the authors of the MBI consider that the syndrome has independent dimensions that not necessarily combine to form a superior body, but it would be enough the presence of one of them on a "high"category to identify this clinical picture, (Briones, 2007). As well as reflecting on whether burnout should be analyzed from a three-dimensional point of view or if on the contrary, it is possible its study with only one of those variables.

Set forth below is the analysis of the structure and internal consistency of the MBI by two leading authors in order to identify the strengths and weaknesses found in the instrument; for example when Burnout was quantified through the MBI, in several times in longitudinal studies was discovered that burnout has consistency coefficients ranging from moderate to high. Furthermore, the crossover time correlations (diachronic) range between 0.50 and 0.60 (Melamed, et al., 2006).

As it can be seen, there are interesting aspects such as international acceptance and empirical support for the factorial structure of the instrument, which are important strengths; however, weaknesses can not be put aside and ignored, because, if not corrected, the results and information from various studies may be inaccurate, biased or incorrect. So, under the view of these data, it is not only prudent, but necessary and unavoidable to propose, tropicalize, adapt, design and validate this and other instruments.

The Spanish researcher Gil-Monte (2004, p. 43) explains for example that: “... some studies report a prevalence of between $6 \%$ and $13 \%$, other studies estimate the prevalence in $35 \%$ and some even conclude that $68 \%$ of workers may be affected by a severe degree of burnout...". Under the same argumentative line, the authors Olivares, et al., (2009) believe that, by using different instruments to measure burnout existing in Latin American countries, it is necessary to be careful and cautious as there is no unanimous and internationally accepted criteria regarding to the cutoff to identify workers with Burnout among those with high job stress but that not necessarily have developed the phenomenon, considering that, even more scientific evidence is needed to estimate the optimal cut point for the various instruments, besides that, if historical, sociological and transcultural aspects are not considered, as it has been mentioned throughout this study, the results may be inflated, and/or outside the scientific canons.

The review of studies on the subject of burnout allows us to conclude that the phenomenon is far too important and the evidence found by the various studies is conclusive, so that the health and labor responsible must consider it in the design of public policies.

\section{Burnout Research in Mexico}

Most of the research done in the country about "burnout" are undergraduate thesis (BA) and postgraduate (see Table 4), which have been made from a medical perspective considering the impact and effects it has on the health of workers, in addition, most of the studies are developed with Spanish and North American instruments.

As can be seen below, of the 241 theses located in 10 Higher Education Institutions (HEIs) in which there is more research on the matter and with free access to their digital libraries, only 4 theses (UNAM) and 1 thesis (IPN) propose an instrument adapted to the characteristics of the organizations, the context and the subjects of study where research has been carried out; but only 1 of them, proposed by a Mexican researcher (Uribe, 2007) who, in addition to doing validation and reliability testing on some existing instruments, has proposed the Mexican Scale of Occupational Wear (EMEDO). Below, areas of further research are presented and thesis that proposed specific instruments for Mexican organizations. 
Table 4. Areas of further research and proposals of specific instruments for Mexican organizations on higher education institutions

\begin{tabular}{ccccccc}
\hline University & $\begin{array}{c}\text { Health } \\
\text { Area }\end{array}$ & $\begin{array}{c}\text { Educational } \\
\text { Area }\end{array}$ & $\begin{array}{c}\text { Other } \\
\text { Areas }\end{array}$ & $\begin{array}{c}\text { Without } \\
\text { Specific Area }\end{array}$ & $\begin{array}{c}\text { Total of } \\
\text { Thesis }\end{array}$ & $\begin{array}{c}\text { Thesis that proposed specific Instruments } \\
\text { for Mexican Contexts }\end{array}$ \\
\hline UNAM & 124 & 19 & 22 & 14 & 179 & 4 \\
BUAP & 15 & 4 & 0 & 1 & 20 & 0 \\
UAM & 13 & 1 & 0 & 1 & 15 & 0 \\
UAEMEX & 9 & 1 & 2 & 0 & 12 & 0 \\
IPN & 3 & 1 & 1 & 0 & 5 & 0 \\
UAG & 1 & 3 & 0 & 0 & 4 & 0 \\
UdeG & 1 & 1 & 1 & 0 & 3 & 0 \\
UASLP & 1 & 0 & 0 & 0 & 1 & 0 \\
UAEH & 1 & 0 & 0 & 0 & 1 & 0 \\
UANL & 0 & 1 & 0 & 0 & 1 & 5 \\
TOTAL & 168 & 31 & 26 & 16 & 241 & \\
\hline
\end{tabular}

Source: Own elaboration based on information from digital libraries.

From the table above, it is concluded that in the selected higher education institutions, researches and theses have focused primarily in the health and educational area; 199 thesis are concentrated in these areas, that if integrated to the 16 thesis developed that have not had the objective of quantifying the Burnout in a profession or specific population and therefore have not used any new or existing instrument, then until now we have only 26 theses that have quantified the phenomenon in another welfare professions. This represents an important finding, since there is a serious deficit in terms of research from universities that aim to study the phenomenon, but do not just focus on these two key areas that account for $85 \%$ of the studies and researches in Mexico. It also highlights the enormous concentration of research at UNAM that accounts for $75 \%$ of the total. In Figure 1, it is shown the two areas that concentrate the number of investigations taking place in Mexico by higher education institutions of the undergraduate and graduate level students.

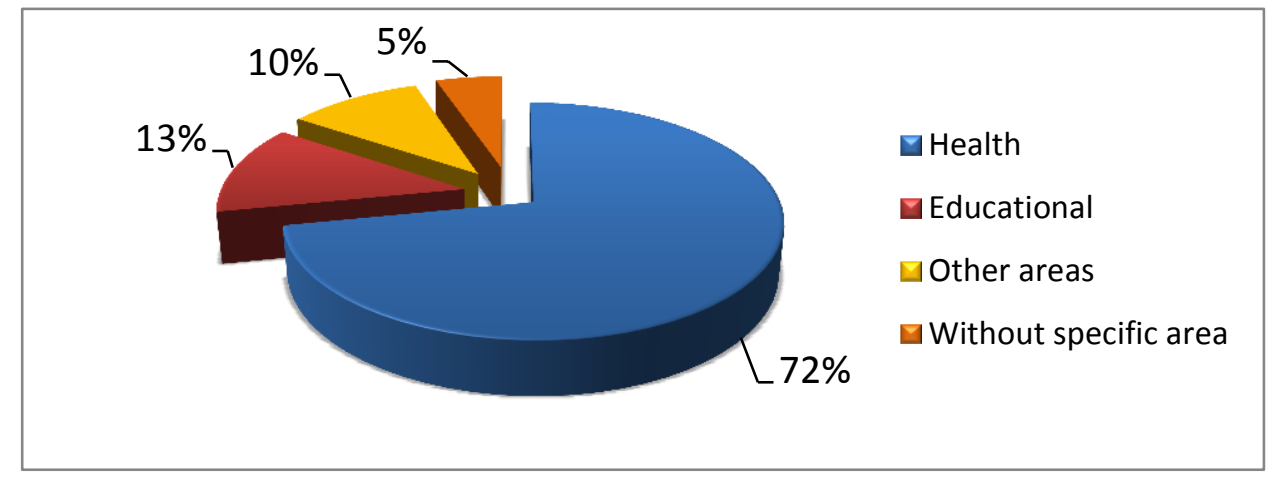

Figure 1. Research on "Burnout" by sector in higher education institutions of Mexico

Source: Own elaboration.

Another finding, is that in tune with international studies on Burnout, in Mexico $98 \%$ of the researches are using the Maslach Burnout Inventory (MBI), in its various versions, to quantify the phenomenon, despite the weaknesses previously exposed of the instrument in question and only $2 \%$ of researches have proposed an appropriate tool for the study of the population and the context in which it is being elaborated and only one of them, the Mexican Scale of Occupational Wear, has been used in more than one study to quantify burnout. It is undeniable to say that it is very important to have instruments that allow reliable quantification; real and accurate, to find the number of workers in our country who have Labor Wear (burnout) at any stage, in order to reverse the 
economic, social and health damage caused by this phenomenon, recalling that not having reliable tools, data and information may cause a wide range of variation that beyond giving clarity on the number of workers with burnout would lead to have misleading results, false and perhaps nonexistent.

Besides the above, the phenomenon has been briefly addressed by Mexican authors in their research, the majority of which are located in the health sector. Likewise $90 \%$ have focused on using the instrument of Maslach (1993) such is the case of (Aranda \& Torres, 2005; Tapia-Hernandez et al., 2005; Barraza, 2006; Palmer, et al., 2007; Camacho-Ávila, et al., 2007; Moreno-Jiménez, et al., 2008; Hernandez-Vargas, et al., 2008; Moreno-Jiménez, et al., 2008) As relevant studies it can be named the El Sahili \& Kornhauser (2010); Barraza-Salas (2012). As noted, few authors have dabbled formally into the study of the phenomenon.

\section{Conclusions}

This paper describes the evolution of the concept, the diverse existing models and measured parameters; noting that, after more than 25 years of formal studies, there is still no single definition accepted by the scientific community. It is known that burnout is an important issue because it is seriously affecting productivity, efficiency, quality in service to users and customers, workers, organizations and society as a whole as it affects the individual's behavior and psychological balance, causing changes in health and in work performance as mentioned by Goicoechea, (2004). This phenomenon has effects and implications worldwide but is particularly important in emerging countries with weak social protection structures where workers live strenuous work days that often are not even remunerated. Such is the case of Mexico where working hours go beyond those established by international bodies such as the World Health Organization and the International Labour Organization.

In a world where half of the working population is unemployed or has an informal job and the other half works excessive hours, the study of burnout and its varieties in vulnerable groups should be on the research agenda of the major universities. In the case of Mexico there is few research of the phenomenon in institutions, even in the case of UNAM, UAM and IPN. The same thing can be seen in the research by academics where most of them are aligned to health and education sectors; but this is not the worst, perhaps the most unfortunate thing is that most researchers are using exclusively the Maslach and Jackson instrument. Another point observed is that scholars have excluded minority group studies that are at risk of suffering the phenomenon such as informal sector workers, policemen and drivers.

Likewise, bibliographical research verifies the enormous popularity that possesses the Maslach Burnout Inventory method, although for many authors does not correspond to its predictive ability and, the accumulation of its weaknesses should involve using other more accurate models adapted to the realities of Latin America.

Besides theses and researches carried out in the Mexican higher education institutions, it is clear that there are other areas of opportunity for further studies on the subject, especially using an administrative approach to determine the economic costs to the public and private sectors, calculating the investment budget of the government used to alleviate the effects of the damage on the health of workers, a review of workloads to make them consistent with the available resources, the redesign of the tasks, the increased participation of workers in decisions that have a positive effect on the achievement of objectives, promoting the participation and collaboration networks in different areas of the organization, the establishment of clear systems of promotion and reward to encourage internal meritocratic culture, the review and updating of operations manuals and procedures that could be causing various situations in different aspects that can generate dissatisfaction, deteriorating of quality and poor service delivery; all of this in order to maintain healthy work environments, productive, efficient, and minimize the damage expenses and financial losses resulting from job wear (burnout).

The main conclusion is that Burnout is an occupational disease whose symptoms are: physical and emotional exhaustion, disappointment and disillusionment, devaluation of the professional role and dysfunction in the workplace. This bibliographical research is a provocation to scholars in order to motivate them to develop their own models focused on risk groups in our country, which are many, like the police, various business workers and service providers among others.

\section{References}

Álvarez, E., \& Fernández, L. (1991). El Síndrome de "Burnout" o el desgaste profesional (I): revisión de estudios. Revista de la Asociación Española de Neuropsiquiatría, XI(39), 257-265. Retrieved from http://www.revistaaen.es/index.php/aen/article/download/15231/15092

Aranda, P., \& Torres M. (2005). Factores psicosociales y síndrome de burnout en médicos de familia. México. Anales de la Facultad de Medicina, 66(3). 
Aveni, M. A., \& Albani, F. (1992). The burnout sindrome in the helping professions: A study of socio-sanitary staff working with the elder persons in different geriatric services in Lombardy area. In J. M. Vía \& E. Portella (Eds.), La sociedad ante el envejecimiento y la minusvalía (Vol. I). Barcelona: S.G. Editores.

Barnett, R., Brennan, R., \& Gareis, K. (1999). A Closer Look at the Measurement of Burnout. Journal of Applied Biobehavioral Research, 2(4), 65-78. http://dx.doi.org/10.1111/j.1751-9861.1999.tb00055.x

Barraza, M. (2006). Síndrome de Burnout: Un estudio comparativo entre profesores y médicos de la ciudad de Durango.

Barraza-Salas, H. (2012). Estrés Laboral y Burnout en docentes de Educación Superior en México. México: Universidad Autónoma de Nayarit (UAN).

Benavides, A. M., Moreno-Jiménez, B., Garrosa, E., \& González, J. L. (2002). La evaluación específica del síndrome de burnout en psicólogos: el "inventario de burnout de psicólogos". Clínica y salud, 13, 257-283.

Blandin J., \& Martínez, D. (2005). Estrés laboral y mecanismos de afrontamiento: su relación en la aparición del Síndrome de Burnout en médicos residentes del Hospital Militar "Dr. Carlos Arvelo". Archivos Venezolanos de Psiquiatría y Neurología, 51(104).

Boyle, G., Grap, M., Jounger, J., \& Thornby, D. (1991). Apoyo Social en el trabajo. Madrid: Síntesis S.A.

Briones, B. (2007). Presencia de Síndrome de Burnout en Poblaciones Policiales vulnerables de Carabineros de Chile. Ciencia y Trabajo Abr-Marz, 9(24), 43-50. Retrieved from http://www.cienciaytrabajo.cl/pdfs/24/pagina\%2043.pdf

Buendía, J., \& Ramos, F. (2001). Empleo, Estrés y Salud. Madrid: Pirámide.

Burke, R. (1987). Burnout in police work: An examination of the Cherniss model. Group and Organization Studies, 12, 174-188. http://dx.doi.org/10.1177/105960118701200205

Buunk, B., \& Schaufeli, W. (1993). Burnout: A perspective from Social Comparison Theory. In W. B. Schaufeli, C. Maslach \& T. Marek (Eds.), Professional Burnout. Recent developments in theory and Research. London: Taylor y Francis.

Camacho-Ávila, A., Juárez, G., \& Arias G. (2007). Síndrome de burnout y factores asociados en médicos estudiantes. Facultad de Psicología, Universidad Autónoma del Estado de Morelos (UAEMor). Red de Investigadores sobre Factores Psicosociales en el Trabajo A.C.

Carmona-Monge, F., Sanz-Rodríguez, L., \& Marín, M. (2002). Clima social laboral y síndrome de Burnout en profesionales de enfermería. en Enfermería Científica, 4(8), 244-245.

Cherniss, C. (1993). The role of profesional self-efficacy in the etiology and ameloriation of burnout. En Schaufeli, W. B., Maslach, C., \& Marck, T. (Eds.), Professional burnout: Recent development in theory and research (pp. 135-149). Washington, D.C: Taylor \& Francis. Retrieved from http://psycnet.apa.org/psycinfo/1993-97794-008

Corcoran, K. (1985). Measuring Burnout: A relaibility and covergent validity study. Journal of Social Behaviour and Personality, 1, 107-112.

Cox, T., Kuk, G., \& Leiter, M. (1993). Burnouts, health, work stress and organizacional healthiness. En W.B. Schaufeli, C. Maslach \& T. Marek (Eds.), Professional burnout: recent developments in theory and research (pp. 177-193). Londres: Taylor y Francis.

Cummings, T. G., \& Cooper, C. L. (1998). A cybernetic theory of organizational stress. In Cooper C. L. (Ed.), Theories of organizational stress (pp. 101-122). Oxford, U.K.: Oxford University Press,.

Dell'Erba, G., Venturi, P., Rizzo, F., Porcus, S., \& Pancheri, P. (1994). Burnout and health status in Italian air traffic controllers. Aviation Space and Environmental Medicine, April, 315-322.

Edelwich, J., \& Brodsky, A. (1980). Burnout: Stages of Disillusionment in the Helping Professions. New York: Human Science Press.

El Sahili, G., \& Ali, L. F. (2010). Psicología para el Docente: consideraciones sobre los riesgos y desafíos de la práctica magisterial (p. 337). Guanajuato: Universidad de Guanajuato.

El Sahili, G., \& Ali, L. F. (2011). Docencia: Riesgos y desafíos (p. 224). México, D. F.: Editorial Trillas.

El Sahili, G., \& Kornhauser, L. (2010). Burnout en el colectivo docente. México: Edición y Producción: 
Universidad EPCA.

Emener, W. G., \& Luck, R. S. (1980). Emener-Luck Burnout Scale. ELBOS.

Europa Press. (2007, 24 Mayo). El estrés cuesta a los europeos 20.000 millones de euros. Retrieved from http://www.elmundo.es/mundodinero/2007/05/24/economia/

Farber, B. (1983). Stress and burnout in the Human Service Professions. New York: Pergamon Press.

Farber, B. (1984). Stress and burnout in suburban teachers. Journal of Educational Research, 77(6), 325-331.

Farber, B. (2000). Treatment Strategies for Different Types of Teacher Burnout. Psychotherapy in Practice, 5(56), 675-689. http://dx.doi.org/10.1002/(SICI)1097-4679(200005)56:5\%3C675::AID-JCLP8\%3E3.0.CO;2-D

Fernández, M., Mayo, M., Oliver, C., Aragoneses, A., \& Moreno, B. (1990). Una escala de evaluación de rol en el ámbito organizacional. Comunicación presentada en el II Congreso Oficial de Psicólogos. Valencia, España.

Ferrer, R. (2004). Quemarse en el trabajo (burnout): 11 perspectivas del burnout. In Martínez, M., Dolz, J. L., Gil-Monte, P. R., Salanova, M., Schaufeli, W. B., Ferrer, R., Alcaine, A., Sopesens, F., Goicoechea, J. M., Moreno, B., Rodríguez, A., Garrosa, E., Morante, M. E., Neveu, J. P., Vallejo, R., \& Polo, F. (Eds.), El Desgaste Professional. Un Riesgo Laboral (pp. 93-111). Madrid: Elgido.

Freudenberger, H. (1974). Staff Burn-Out. Journal of Social Issues, 30(1), 159-166. Retrieved from http://dx.doi.org/10.1111/j.1540-4560.1974.tb00706.x

Friedman, I. (1995). Student behavior patterns contributing to teacher burnout. Journal of Educational Research, 88(5), 281-289. http://dx.doi.org/10.1080/00220671.1995.9941312

Gann, M. L. (1979). The role of personality factors and job characteristics in bumout: A study of social service workers. Doctoral dissertation, University of California-Berkeley, University of California.

Garcés, E. (1994). Burnout: Un acercamiento teórico-empírico al constructo en contextos deportivos. Tesis de licenciatura. Murcia: Universidad de Murcia.

García, J, M., Herrero, S., \& León, J, L. (2007). Validez factorial del MBI en una muestra del hospital psiquiatrico penitenciaria de Sevilla. Apuntes de psicología, 2(25), 157-174.

García, M., Sobrido, N., García, M., Raña, C., \& Saleta, J. L. (1995). El síndrome burnout en profesionales de enfermería. Enfermería Científica, 202-203, 61-64.

García-Izquierdo, M. (1991). Burnout en profesionales de enfermería de Centros Hospitalarios. Revista de Psicología del Trabajo y de las Organizaciones, 7(18), 3-12.

García-Izquierdo, M. (1995). Evaluación del burnout: estudio de la fiabilidad, estructura empírica y validez de la escala EPB. Ansiedad y Estrés, 1(2-3), 219-229.

García-Izquierdo, M., \& Velandrino, A. (1992). EPB: Una escala para la evaluación del burnout profesional de las organizaciones. Anales de Psicología, 8(1-2), 131-138.

García-Izquierdo, M., Castellón, M., Albadalejo, B., \& García-Izquierdo, A. L. (1993). Relaciones entre el burnout, ambigüedad de rol y satisfacción laboral en el personal de banca. Revista de Psicología del Trabajo y de las Organizaciones, 11(24), 17-26.

García-Izquierdo, M., Llor, B., \& Sáez, C. (1994). Estudio comparativo de dos medidas de burnout en personal sanitario. Anales de Psiquiatría, 10(5), 180-184.

Garden, K. (1987). Comparation of two measures of burnout. Psychological reports, 53(1), $283-289$.

Gillespie, D. (1980). Correlates for active and passive burnout types of burnout. Journal of Social Service Research, 4(2), 1-16. http://dx.doi.org/10.1300/J079v04n02_01

Gillespie, D., \& Numerof, R. (1984). The Gillespie-Numerof Burnout Inventory: tecnical manual. San Luis: Washington University.

Gil-Monte, P. (1994). El síndrome de burnout: un modelo multicausal de antecedentes y consecuentes en profesionales de enfermería. Disertación doctoral no publicada, Facultad de Psicología, Universidad de La Laguna.

Gil-Monte, P. (2003a). Burnout syndrome: Síndrome de quemarse por el trabajo, desgaste profesional, estrés laboral o enfermedad de Tomás? Revista de Psicología del Trabajo y de las Organizaciones, 19(2), $181-197$. Retrieved from http://www.redalyc.org/src/inicio/ArtPdfRed.jsp?iCve=231318052004 
Gil-Monte, P. (2003b). El síndrome de quemarse por el trabajo (síndrome de burnout) en profesionales de enfermería. Revista de Psicología Científica, 1, 19-33. Retrieved from http://www.psicologiacientifica.com/bv/psicologiapdf-78-el-sindrome-de-quemarse-por-el-trabajo-(sindrom e-de-burnout)-aproximaciones-teor.pdf

Gil-Monte, P. (2004). Quemarse en el trabajo (burnout): 11 perspectivas del burnout. In Martínez, M., Dolz, J. L, Gil-Monte, P., Salanova, M., Schaufeli, W. B., Ferrer, R., Alcaine, A., Sopesens, F., Goicoechea, J. M., Moreno, B., Rodríguez, A., Garrosa, E., Morante, M. E., Neveu, J. P., Vallejo, R., \& Polo, F. (Eds.), El Síndrome de Quemarse por el Trabajo (Burnout): Una Perspectiva Histórica (pp. 37-71). Madrid: Elgido.

Gil-Monte, P. (2005). El síndrome de quemarse por el trabajo (Burnout): una enfermedad laboral en la sociedad del bienestar. Madrid, España: Pirámide.

Gil-Monte, P., \& Peiró, J. M. (1998). A longitudinal study on burnout syndrome in nursing professionals. Quaderni di Psicologia del Lavoro, 5(Feelings work in Europe), 407-414.

Gil-Monte, P., \& Peiró, J. M. (1999a). Perspectivas teóricas y modelos interpretativos para el estudio del síndrome de quemarse por el trabajo. Anales de Psicología, 15(2), 261-268.

Gil-Monte, P., \& Peiró, J. M. (1999b). Validez factorial del Maslach Burnout Inventory en una muestra multiocupacional. Psicothema, 11(3), 679-689.

Gil-Monte, P., \& Peiró, J. M. (2000). Validez factorial del Maslach Burnout Inventory en una muestra multiocupacional. Universidad de La Laguna y Universidad de Valencia. Psicothema, 3(11), 679-689.

Gil-Monte, P., Núñez, E., \& Selva, Y. (2006). Relación entre el Síndrome de Quemarse por el Trabajo (Burnout) y síntomas cardiovasculares: un estudio en técnicos de prevención de riesgos laborales. Revista Interamericana de Psicología, 40(2), 227-232.

Goicoechea, J. (2004). Quemarse en el trabajo (burnout): 11 perspectivas del burnout. In Martínez, M., Dolz, J. L., Gil-Monte, P., Salanova, M., Schaufeli, W. B., Ferrer, R., Alcaine, A., Sopesens, F., Goicoechea, J. M., Moreno, B., Rodríguez, A., Garrosa, E., Morante, M. E., Neveu, J. P., Vallejo, R., \& Polo, F. (Eds.), Aportaciones de la medicina del trabajo en la prevención del Síndrome de Desgaste Profesional o Burnout (pp. 147-160). Madrid: Elgido.

Golembiewski, R., Munzenrider, R., \& Carter, D. (1983). Progresive Phases of Burnout and Their Worksite Covariants. Journal of Applied Behavioral Science, $19, \quad 464-481$. http://dx.doi.org/10.1177/002188638301900408

Golembiewski, R., Munzenrider, R., \& Stevenson, J. G. (1984). Physical symptoms and burnout phases. Segunda Conferencia Anual sobre Política y Desarrollo Organizacional. Lousville: Universidad de Lousville.

Guerrero, E., \& Vicente, F. (2001). Syndrome de "Burnout” o desgaste profesional y afrontamiento del estrés en el profesorado. Universidad de Extremadura.

Hernández-Vargas, C. I., Dickinson, M. E., \& Fernández, O. (2008). El síndrome de desgaste profesional Burnout en médicos mexicanos. Rev. Facultad de Medicina de la Universidad Nacional Autónoma de México UNAM, 51(1), 45-67.

Hobfoll, S., \& Freddy, J. (1993). Conservation of resources: A general stress theory applied to burnout. In W.B. Schaufeli, C. Maslach \& T. Marek (Eds.), Professional burnout: Recent development in theory and research (pp. 115-129). London: Taylor \& Francis.

Hock, R. (1988). Professional burnout among public school teachers. Public Personnel Management, 17, $167-189$.

Holland, P., \& Michael, W. (1993). The concurrent validity of the Holland Burnout Assessment Survey for a sample a middle school teachers. Educational and Psychological Measurement, 53, 1067-1077. http://dx.doi.org/10.1177/0013164493053004019

Houkes, I., Janssen, P., de Jonge, J., \& Nijhuis, F. (2001). Specific relationships between work characteristics and intrinsic work motivation, burnout and turnover intention: A multi-sample analysis. European Journal of Work and Organizational Psychology, 10, 1-23. http://dx.doi.org/10.1080/13594320042000007

Janssen, P., de Jonge, J., \& Bakker, A. (1999). Specific determinants of intrinsic work motivation, burnout and turnover intentions: a study among nurses. Journal of Advanced Nursing, 29(6), 1360-1369. http://dx.doi.org/10.1046/j.1365-2648.1999.01022.x 
Jones, J. W. (1980). Staff Burnout Scale for Health Professionals (SBS-HP). Park Ridge, Illinois: London House.

Kremer, L., \& Hofman, J. E. (1985). Teachers'professional identity and burn-out. Research in Education, 34, 89-95.

Lee, R., \& Ashforth, B. (1993). A longitudinal study of burnout among supervisors and managers: Comparisons between the Leiter and Maslach (1988) and Golembiewski (1986) models. Organizational Behavior and Human Decision Processes, 54, 369-398. http://dx.doi.org/10.1006/obhd.1993.1016

Leiter, M., \& Maslach, C. (1988). The impact of interpersonal environment on burnout and organizational commitment. Journal of Organizational Behavior, 12, 123-144. http://dx.doi.org/10.1002/job.4030090402

Leiter, M., Maslach, C., \& Jackson, S. E. (1996). Maslach Burnout Inventory: Manual (3rd ed.). Palo Alto: Consulting Psychologists Press.

Levi, L. (2003). Guidance on work-related stress. Belgium: Agency for Safety and Health at Work.

Manzano, G. (2001). Estrés crónico laboral asistencial (Burnout) en las Administraciones Públicas. Revista de dirección, organización y administración de empresas, 25, 148-159. Retrieved from http://www.revistadyo.com/index.php/dyo/article/view/230/230

Marrau, C. (2004). El síndrome de Burnout y sus posibles consecuencias en el trabajador docente. Fundamentos en humanidades, 10, 53-68. Retrieved from http://dialnet.unirioja.es/servlet/articulo?codigo=2004369

Marrau, C. (2009). El Síndrome de Quemarse por el Trabajo (Burnout), en el marco contextualizador del estrés laboral. Fundamentos en Humanidades Universidad Nacionalde San Luis - Argentina, X(I), 167-177. Retrieved from http://redalyc.uaemex.mx/src/inicio/ArtPdfRed.jsp?iCve=18411965010

Martínez, A. (2010). El Síndrome de Burnout. Evolución conceptual y estado actual de la cuestión. Vivat Academia, 112.

Martínez, M. P. (2012). Crece empleo informal en México. El Economista. Retrieved from http://eleconomista.com.mx/industrias/2012/04/26/crece-empleo-informal-mexico

Maslach, C. (1982). Burnout: The cost of caring. Nueva York: Prentice-Hall Press.

Maslach, C. (1993). Burnout: a multidimensional perspective. In Schaufeli, W. B., Maslach. C., \& Marek, T. (Eds.), Professional burnout: Recent developments in theory and research (pp. 19-32). Washington, DC: Taylor y Francis.

Maslach, C. (1998). A multidimensional theory of burnout. In Cooper, C. L. (Ed.), Theories of organizational stress (pp. 68-85). Oxford, U.K. Oxford University Press.

Maslach, C. (2009). Comprendiendo el Burnout. Ciencia y Trabajo Abr-Jun, 11(32), 37-43.

Maslach, C., \& Jackson, S. (1981a). The measurement of experienced burnout. Journal of occupational behavior, 2(2), 99-113. http://dx.doi.org/10.1002/job.4030020205

Maslach, C., \& Jackson, S. (1981b). MBI: Maslach Burnout Inventory. Manual. Palo Alto: University of California, Consulting Psychologists Press.

Maslach, C., \& Jackson, S. (1986). Escale Maslach Burnout Inventory. Journal of occupational behavior, 8(3), $23-45$.

Maslach, C., \& Pines, A. (1977). The burn-out syndrome in the day care setting. Child Care Quarterly, 6, 100-113. http://dx.doi.org/10.1007/BF01554696

Maslach, C., Schaufeli, W., \& Leiter, M. (2001). Job burnout. Annual Review of Psychology, 52, 397-422. http://dx.doi.org/10.1146/annurev.psych.52.1.397

Matthews, D. B. (1990). A comparison of burnout in selected occupational fields. Career Development Quaterly, 38(3), 230-239. http://dx.doi.org/10.1002/j.2161-0045.1990.tb00385.x

Melamed, S., Shirom, A., Toker, S., Berliner, S., \& Shapira, I. (2006). Burnout and risk of cardiovascular disease: Evidence, possible causal paths and promising research directions. Psychologycal Bulletin, 132(3), 327-353. http://dx.doi.org/10.1037/0033-2909.132.3.327

Merodio, C. (2003). Eficacia crítica de los modelos de trabajo en grupo con personas con discapacidad. In Juan Carlos (Ed.), Rehabilitación clínica integral: funcionamiento y discapacidad (p. 496). Barcelona: Elsevier España.

Mingote, J. (1998). Síndrome de Burnout o Síndrome de Desgaste Profesional. Formación médica continuada, 
5(8), 493-509.

Moreno-Jiménez, B., \& Oliver, C. (1993). El MBI, como escala de estrés en profesiones asistenciales y nuevas versiones. In M. Pons \& M. T. Arguera (Eds.), Aportaciones a la Evaluación Psicológica (pp. 161-174). Barcelona: P.P.U.

Moreno-Jiménez, B., Bustos, R., Matallana, A., \& Miralles, T. (1997). La evaluación del Burnout. Problemas y alternativas. El CBB como evaluación de los elementos del proceso. Revista del trabajo y de las organizaciones, 13(2), 185-207.

Moreno-Jiménez, B., Garrosa, E., \& González, J. L. (2000a). El desgaste profesional de enfermería. Desarrollo y validación factorial del CDPE. Archivos Prevención de Riesgos Laborales, 3(1), 18-28.

Moreno-Jiménez, B., Garrosa, E., \& González, J. L. (2000b). La evaluación del estrés y el burnout del profesorado: el CBPR. Revista de Psicología del Trabajo y las Organizaciones, 16, 151-171.

Moreno-Jiménez, B., Garrosa, E., Gálvez, M., González, J. L., \& Benavides-Pereira, A. M. (2002). A avalaiçao do burnout em profesores. Comparaçao de instrumentos: CBP-R e MBI-Ed. Psicología em Estudo, 7(1), 11-19. http://dx.doi.org/10.1590/S1413-73722002000100004

Moreno-Jiménez, B., González, J., \& Garrosa, E. (2001). Desgaste profesional (burnout), personalidad y salud percibida. In J. Buendía \& F. Ramos (Eds.), Empleo, estrés y salud (pp. 59-83). Madrid: Pirámide.

Moreno-Jiménez, B., Macarena, G., Garrosa, H., \& Mingote, A. (2006). Nuevos planteamientos en la evaluación del burnout. La evaluación específica del desgaste profesional médico. Atención primaria: Publicación Oficial de la Sociedad Española de Familia y Comunitaria, 10 (38), 544-549, ISSN 0212-6567.

Moreno-Jiménez, B., Meda, L., Morante, B., Rodríguez, M., \& Palomera, C. (2006). Validez factorial del inventario burnout de psicólogos en una muestra de psicólogos mexicanos. Revista latinoamericana de psicología, 3(38), 445-456.

Moreno-Jiménez, B., Meda, L., Rodríguez, M., Palomera, C., \& Morales, L. (2008). El síndrome de burnout en una muestra de psicólogos mexicanos: prevalencia y factores sociodemográficos asociados. Psicología y Salud, enero-junio, 16(1). Universidad Veracruzana Xalapa, México.

Moreno-Jiménez, B., Oliver, C., \& Aragoneses, A. (1991). El Burnout, una forma específica de estrés laboral. In F. Buela-Casal \& V. E. Caballo (Eds.), Manual de psicología clínica aplicada (pp. 271-289). Madrid: Siglo XXI.

Moreno-Jiménez, B., Oliver, C., \& Aragoneses, A. (1993). Configuración específica del estrés laboral asistencial en el profesorado de educación media. Madrid, España: Centro Nacional de Investigación Educativa (CIDE).

Napione, B. (2008). Cuándo se quema el profesorado de secundaria? Madrid: Ediciones Díaz de Santos (p. 436).

Notimex. (2013, marzo 5). Desempleo en Europa llega a cifras récord. El Economista. Retrieved from http://eleconomista.com.mx/economia-global/2012/03/01/desempleo-europa-llega-cifras-record

Olabarría, B., \& Mansilla, F. (2007). Ante el Burnout: Cuidados a los Equipos de Salud Mental. Revista de Psicopatología y Psicología Clínica, 12(1), 1-14. http://dx.doi.org/10.5944/rppc.vol.12.num.1.2007.4029

Olivares, V. E., \& Gil-Monte, P. (2009). Análisis de las Principales Fortalezas y Debilidades del "Maslach Burnout Inventory" (MBI). Rev. Ciencia y Trabajo, 5, 161-164.

Olivares, V., Vera, A., \& Juárez, A. (2009). Prevalencia del Síndrome de Quemarse por el Trabajo (Burnout) en una Muestra de Profesionales que Trabajan con Profesionales que Trabajan con Personas con Discapacidades en Chile. Ciencia y Trabajo Abr-Jun, 11(32), 63-71. Retrieved from http://www.cienciaytrabajo.cl/pdfs/32/pagina63.pdf

Oliver, C., Pastor, J. C., Aragoneses, A., \& Moreno, B. (1990). Una teoría y una medida de estrés laboral asistencial. Comunicación presentada al II Congreso del colegio Oficial de Psicólogos. Valencia España.

Organisation for Economic Co-operation and Development. (2013). Society at a Glance 2013 - OECD Social Indicators (p. 8). Retrieved from http//www.oecd.org/els/social/indicators/SAG

Palmer. M., Prince V., Searc B., \& Compean S. (2007). Prevalencia del síndrome de "burnout" en el personal de enfermería de 2 hospitales mexicanos. Enfermería Clínica, 5(17), 256-260. http://dx.doi.org/10.1016/S1130-8621(07)71810-7

Perlman, B., \& Hartman, E. (1982). Burnout: Summary and future research. Human Relations, 35, 283-385. 
http://dx.doi.org/10.1177/001872678203500402

Petegrew, L. S., \& Wolf, C. E. (1981). Validating measure of teacher stress. American Educational Research Journal, 19, 372-390. http://dx.doi.org/10.3102/00028312019003373

Pines, A., \& Aronson, E. (1986). Burnout professional. New York: Free Press.

Pines, A., \& Aronson, E. (1988). Career Burnout: Causes and cures. New York: The Free Press.

Pines, A., \& Kafry, D. (1982). Coping with burnout. In J. W. Jones (Ed.), The burnout syndrome: current research, theory, interventions (pp. 139-150). Park Ridge, Illinois: London House Press.

Pines, A., Aronson, E., \& Kafry, D. (1981). Burnout: from tedium to personal growth. Nueva York: Free Press.

Ponce, C., Bulnes, M., Aliaga, J., Atalaya, M., \& Huertas, R. (2005). El síndrome del "quemado" por estrés laboral asistencial en grupos de docentes universitarios. Revista IIPSI, 8(2), 87-112. Retrieved from http://www.dialnet.unirioja.es/servlet/ fichero_articulo?codigo=2238169

Price, D., \& Murphy, P. (1984). Staff burnout in the perspective of grief theory. Death Education, 8(1), 47-58. http://dx.doi.org/10.1080/07481188408251381

Quiceno, J., \& Vinaccia, S. (2007). Burnout: "Síndrome de Quemarse en el Trabajo (SQT)". Acta Colombiana de Psicología, 122. Retrieved from http://www.redalyc.org/articulo.oa?id=79810212

Ramos, F. (1999). El Sindrome de Burnout. Madrid: Klinik, S.L.

Salanova, M., \& Schaufeli, W. (2004). Quemarse en el trabajo (burnout): 11 perspectivas del burnout. En Martínez, M., Dolz, J. Gil-Monte, P., Salanova, M., Schaufeli, W., Ferrer, R., Alcaine, A., Sopesens, F., Goicoechea, J., Moreno, B., Rodríguez, A., Garrosa, E., Morante, M., Neveu, J., Vallejo, R., \& Polo, F. (Eds.), La ilusión por el trabajo (Engagement): El lado positivo del Burnout? (pp. 72-92). Madrid: Elgido.

Schaufeli, W., \& Buunk, B. P. (2003). Burnout: An overview of 25 years of research in theorizing. In M. J. Schabracq, J. A. M. Winnubst, \& C. L. Cooper (Eds.), The handbook of work and health psychology (pp. 383-425). Chichester: Wiley. http://dx.doi.org/10.1002/0470013400.ch19

Schaufeli, W., \& Enzmann, D. (1998). The burnout companion to study and practice: a critical analysis. London: Taylor \& Francis.

Schaufeli, W., \& Van Dierendonck, D. (1993). The construct validity of two burnout measures. Journal of Organizational Behavior, 14, 631-647. http://dx.doi.org/10.1002/job.4030140703

Schaufeli, W., Leiter, M. P., Maslach, C., \& Jackson, S. E. (1996). The Maslach Burnout Inventory: General Survey (MBI-GS). En C. Maslach, S. E. Jackson \& M. P. Leiter (Eds.), Maslach Burnout Inventory Manual (3rd ed., pp. 19-26). Palo Alto, California: Consulting Psychologists Press.

Schwab, R. L. (1986). Burnout in education. In C. Maslach \& S. E. Jackson (Eds.), Maslach Burnout Inventory (2nd ed., pp. 18-22). Palo Alto, California: Consulting Psychologists Press.

Seidman, S., \& Zager, J. (1986). The Teacher Burnout Scale. Educational Research Quaterly, 11(1), 26-33.

Shirom, A. (2009). Acerca de la Validez del Constructo, Predictores y consecuencias del burnout en el lugar de trabajo. Ciencia y Trabajo Abr-Jun, 11(32), 44-54. Retrieved from $\mathrm{http}: / /$ www.cienciaytrabajo.cl/pdfs/32/pagina44.pdf

Soler, J., Yaman, H., Esteva, M., Dobbs, F., Asenova, R., \& Katic, M. (2008). Burnout in European family doctors: the EGPRN study. Family Practice Advance Access, 25(4), 245-265. http://dx.doi.org/10.1093/fampra/cmn038

Starrin, B., Larsson, G., \& Styborn, S. (1990). A review and critique of psychological approaches to the burn-out phenomenon. Scandinavian Journal of Caring Sciences, 4(2), 83-91. http://dx.doi.org/10.1111/j.1471-6712.1990.tb00050.x

Tapia-Hernández, T., Ávalos-García, M., César-Vargas, R., Franco-Alcántar, R., Alonso C., Gómez A., \& Rodríguez-Orozco. A. (2005). Sindrome de burnout en enfermeras de un hospital regional. Universidad Michoacana, San Nicolás de Hidalgo, Morelia, Michoacán, México.

Thompson, M. S., Page, S. L., \& Cooper, C. L. (1993). A test of Caver and Scheier's self-control model of stress in exploring burnout among mental health nurses. Stress Medicine, 9, 221-235. http://dx.doi.org/10.1002/smi.2460090405

Tifner, S., Martín, P., Albanesi, S., \& Bortoli, M. (2006). Burnout en el colectivo docente. Revista de 
Humanidades, 12, 279-291. Retrieved from http://dialnet.unirioja.es/servlet/articulo?codigo=2542032

Uribe, F. (2007). Estudio Confirmatorio de la Escala Mexicana de Desgaste Ocupacional (EMEDO): Un instrumento de Burnout para Mexicanos. Revista Interamericana de Psicología Ocupacional, 26(1), 7-21.

Vallejo, R. (2004). Quemarse en el trabajo (burnout): 11 perspectivas del burnout. In Martínez, M., Dolz, J., Gil-Monte, P., Salanova, M., Schaufeli, W., Ferrer, R., Alcaine, A., Sopesens, F., Goicoechea, J., Moreno, B., Rodríguez, A., Garrosa, E., Morante, M., Neveu, J., Vallejo, R., \& Polo, F. (Eds.), El Burnout; El Síndrome de Estar o Sentirse Quemado. Aspectos Jurídicos Preventivos y Reparadores del Daño o Lesión (pp. 213-255). Madrid: Elgido.

Venturi, P., Rizzo, F., \& Dell'Erba, G. (2006). Studio di validazione di un nuovo strumento per la valutazione della síndrome di burnout, it Rome Burnout Inventory. Medicina Psicosomática, 8(4), 56-78.

Walker, G. (1986). Burnout: From metaphor to ideology. Canadian Journal of Sociology, 11(1), 35. http://dx.doi.org/10.2307/3340447

Winnubst, J. (1993). Organizational structure, social support, and burnout. In W. B. Schaufeli, C. Maslach \& T. Marek (Eds.), Professional burnout: Recent developments in theory and research (pp. 151-162). Washington D.C.: Hemisphere.

\section{Copyrights}

Copyright for this article is retained by the author(s), with first publication rights granted to the journal.

This is an open-access article distributed under the terms and conditions of the Creative Commons Attribution license (http://creativecommons.org/licenses/by/3.0/). 